\title{
The Undiscover'd Country: Theatrical Space Without in Hamlet
}

Hanna Scolnicov

\section{(2) OpenEdition}

Journals

\section{Electronic version}

URL: http://journals.openedition.org/shakespeare/518

DOI: 10.4000/shakespeare.518

ISSN: 2271-6424

\section{Publisher}

Société Française Shakespeare

Printed version

Date of publication: 1 November 1989

Number of pages: 95-107

\section{Electronic reference}

Hanna Scolnicov, "The Undiscover'd Country: Theatrical Space Without in Hamlet », Actes des congrès de la Société française Shakespeare [Online], 6 | 1989, Online since 01 January 2007, connection on 01 May 2019. URL : http://journals.openedition.org/shakespeare/518; DOI : 10.4000/shakespeare.518 


\section{SOCIETE FRANCAISE SHAKESPEARE}

\section{Actes du Congrès - 1984}

\section{LIEU ET TEMPS}

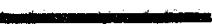

Directeur de la publication Jean FUZIER 


\section{The Undiscover'd Country : Theatrical Space Without in Hamlet}

Theatre space is an architectural concept. The theatre space is the shell or the hulk within which each performance creates its theatrical space. It is a fixed space, the dimensions and parts of which have been predetermined by the architect or by the chosen site of the production. Unlike the theatre space, the theatrical space is created anew by every production. The play itself implies a theatrical space, which director, scenographer and actors struggle to realize, translating it into the concrete terms of a particular production. The given theatre space must be reconciled with this implied theatrical space, it must be assigned a meaning in accordance with the needs of the play. While the actors move in a theatre space, the characters function within a theatrical space.

But the play may also define spaces which, although crucial to the plot, are to remain unseen in the actual production. These are off-stage spaces, from which the characters are supposed to enter or 
to which they exit. They may be close at hand, as for example an intriguing next-door room, or far-off, as an overseas country to which a character may travel. These spaces are indicated in the simplest form in the Roman theatre, where, by convention, one exit leads to the city, the other to the country or the harbour. Even though such spaces may never be shown on stage, events of great moment may take place in them. Any such space implied by the play but not constituting part of the spectacle, i.e. not realized on stage, I shall call a theatrical space without. ${ }^{1}$

However, the theatrical space without is not defined in merely negative terms, as that space which is not visible on stage. On the contrary, it is delimited and defined by the play itself. The theatrical space without is not identical with the audience's everyday space. A character who leaves the stage is presumed to be going to some other theatrical space, not just to the actor's dressing-room.

The relation between the theatrical space within and the theatrical space without may be further clarified by making use of Chaim Perelman's distinction, in a note on Salvador Dali, between espace perçu and espace conçu. ${ }^{2}$ For the audience, the theatrical space within is perceived space, while the theatrical space without, although no less credible, is a merely conceived space.

In Hamlet, the articulation of space is not merely theatrically functional, but also serves as both a structural and thematic principle. Practically all the scenes of the play take place in the castle of Elsinore. Whether on the battlements or in the state room or in private feminine closets, the scene remains within the castle walls. This enclosed space is responsible for the claustrophobic atmosphere of the play. "Denmark's a prison" is a psychological as well as a thematic expression of the relatively confined quarters which constitute the theatrical space of the play.

A theatrical space without complements the visible Elsinore. Beyond the insular castle there is what I shall call a " virtual geography " : a geographical space which is never seen but is nevertheless constantly evoked in the play. Beyond Elsinore, we hear of England, Wittenberg, Paris, Norway and Poland. These are not only mentioned by name, but there is a steady movement of characters between them and the circumscribed spatial core of Elsinore. Vast as this geography is, it too is comprised of a finite number of particular places with 
specific characteristics. The back and forth movement between Elsinore and its geographical periphery shapes the action of the play, and provides it with a dynamic principle.

But the spatial conception of the play goes beyond both the actual confines of the theatrically depicted Elsinore and the theatrically imagined geography. Beyond them lies

The undiscover'd country, from whose bourn

No traveller returns.

(III $1,78-79)$

Here then is another theatrical space without, a space different in kind from the geographical space previously outlined. The undiscover'd country is a non-place defined in spatial terms. It is unknown terrain, unexplored and unlimited. This space beyond space is only known as far as its bourn.

The theatrical spaces in the play may be visualized as arranged in three concentric circles. The core is formed by the visible space, i.e. Elsinore Castle. The second circle is formed by the virtual geography, and the third and outermost of the concentric circles is that country from which no traveller returns.

Within this neat tripartite concentric structure, Shakespeare inserts a fourth theatrical space, of a different order. This is the theatrical space defined by the play-within-the-play. It is clearly marked off from the play's three theatrical spaces, but it stands in an interesting and complex relation to them.

"O God", says Hamlet, "I could be bounded in a nutshell, and count myself a king of infinite space" (II 2, 254-255). In this statement Hamlet differentiates between the objective and the subjective perceptions of space. His sense of confinement in Denmark is not shared by his interlocutors, Rosencrantz and Guildenstern, which proves that 
... there is nothing either good or bad, but thinking makes it so. To me it is a prison.

It is indeed a polite form of house-arrest which Claudius imposes on the prince when he refuses to grant him leave to return to Wittenberg. Apart from his short and forced trip to England, Hamlet never leaves the confines of the castle.

Elsinore provides a closed scene for the deadly struggle between uncle and nephew. Until their mutual suspicions are confirmed and the conflict bursts into the open, the struggle is covert and circumspect. Claudius, clearly the more powerful of the two, chooses to keep Hamlet at home, and under constant surveillance. There is little privacy for Hamlet in the castle : even his most intimate encounters, with his mother and with Ophelia, are carefully monitored. It is this constant spying that creates the suffocating atmosphere of the play.

With few minor exceptions, the scene remains Elsinore throughout the play, thus observing dramatic propriety and at the same time creating a dense and concentrated action. While leaving the unity of place intact, the wider geographical context provides the action with an important perspective. The choice of Wittenberg points to a Humanist and Protestant orientation, while Paris suggests a gayer, less inhibited atmosphere. In contrast to the feudal and Gothic atmosphere which pervades the castle, the wider geography suggests the vastness of the Renaissance world and the new educational and ethical ideas pursued in the great Universities.

The space without is defined in terms of the characters' travels to and from particular places. Other real places not specifically mentioned in the play do not form part of this virtual geography. It is England, Norway, Poland and the two university towns, Wittenberg and Paris, that are the outposts of the theatrical space.

The list of travels in the play is almost on a modern scale. Voltemand and Cornelius are the ambassadors dispatched to Norway on a delicate diplomatic mission (I 2). Laertes is granted permission to return to France, presumaly to carry on his studies in Paris (cf. II 1). At the same time, Hamlet is refused permission to return to Wittenberg. In the same scene, we also find out that Horatio had left Wittenberg to attend the late King's funeral. By Act II scene 2. 
Voltemand and Cornelius have already returned from Norway, and Rosenkrantz and Guildenstern have been hastily summoned home, apparently also from Wittenberg. In the interim, Polonius has found time to send his trusted man Reynaldo with some money to Laertes in Paris.

The arrival of tragedians from the city also brings with it a whiff of the outside world. Their warm reception captures the excitement with which Shakespeare's contemporaries must have welcomed a London company on a provincial tour. The players are depicted as cultural ambassadors from the big city with its fashionable bustle of rival theatres. The city remains unnamed, although its identity is unmistakable. ${ }^{3}$ The theatrical life of the city, together with the intelectual activity of the two Universities, stamp the theatrical space without as vital and stimulating.

The big city, with its rich cultural life and fierce commercial competition, appeals to the imagination of the young prince. Elsinore is seen as a rather dreary place for young noblemen. Hamlet's peers prefer the intellectual and cultural challenges afforded by the great Universities to life in court, the tedium of which is only broken by the occasional entertainment. If Wittenberg is to be imagined as another Cambridge, with its rich web of student life and with amateur theatrics in abundance, then it is clear why the young intellectual prince should be attracted back to it.

In developing his theory of the textual history of the play, J. M. Nosworthy convincingly argues that Shakespeare imposed

a background of scholarship upon the basically alien plot material... in deference to the interests of a particular audience, which cannot have been other than an academic one. ${ }^{4}$

Nosworthy takes his cue from the Q1 title page reference to the play as having been acted "in the two universities of Cambridge and Oxford ". The academic audience for which the play was originally written would find it easy to identify with the protagonists of the play.

Last on the list of journeys to be undertaken is Hamlet's trip to England. No sooner does he embark (IV 3) than Laertes comes back from Paris seeking revenge (IV 5). But Hamlet never gets to England. 
He intercepts the King's letter, discovers the plot, and returns to Denmark. There the stage is already set for the last court entertainment - the duel. As all the protagonists of the play are killed in this final scene, it is left to the Norwegian heir Fortinbras, an outsider from the space without, to seize the crown.

The basic spatial structure of the play is that of an action taking place in an extremely limited environment with various characters commuting between it and a wider geographical context. Elsinore is the vortex of the action, into which characters are drawn from the geographical periphery. This wider space is not visually represented in the theatre, but is imaginatively conceived. Its very spaciousness makes the confining boundaries of the perceived Elsinore even narrower by contrast. Compared with the attractive centres of learning and the big city, Elsinore castle is provincial, feudal and oppressive. In other words, the visible theatrical space is defined in relation to its geographical and cultural periphery.

\section{III}

A further dimension is afforded by " the undiscover'd country, from whose bourn no traveller returns " (III 1, 78-79). This is a noncountry conceived in geographical terms. It sets itself for comparison with the truly geographical places. Unlike them, it is " undiscover'd ", unknown except for its boundaries, the boundaries between life and death. If the geographical places are characterized by the frequent comings and goings between them and Elsinore, the undiscover'd country is characterized by departures only. As no one comes back from that country, nothing is know about it. Thus the geographical metaphor is turned inside out so as to expose its own inadequacy for describing the indescribable.

The undiscover'd country is not just another instance of a theatrical space without. Unlike the virtual geography, it cannot even be conceived. While the geographical periphery of Elsinore can be described and imagined in positive terms, the undiscover'd country can be referred to only negatively, as that country from which " no traveller returns". 
The unidirectionality of life, as opposed to the reversibility of movement in space, is also puzzled over in Hamlet's quibbling with Polonius :

... for yourself, sir, shall grow old as I am, if like a crab you could go backward.

(II 2, 202-204)

But the appearance of the Ghost seems to undermine the conception of the unidirectionality of travel to the undiscover'd country. The very action of the play seems to contradict its rhetoric, for here is a recognizable spirit returned from the dead to the quick. Hamlet himself spells out this unnatural course of events, the canonized bones bursting their cerements, the dead corpse leaving the marble sepulcre (I 4, 46-53). But even the Ghost's visit does not reveal any of the secrets of the undiscover'd country, for "I am forbid to tell the secrets of my prison-house " (I 5, 13-14). What he does reveal belongs to another time, not another space, as the murder took place in the castle orchard, i.e. within the confines of Elsinore.

The purpose of the Ghost's visit is to disclose a secret of the past. The murder is antecedent to the events of the play, and therefore outside the scope of the plot. ${ }^{5}$ Yet it is the crucial happening from which the whole chain of events of the play emanates. Shakespeare's dramatic structure begins not with the act of horror but with its narration by the victim. The murder, an actual event that took place in Elsinore, has left no traces, has had no witnesses. The expository function fulfilled by the Ghost is of a different order from that of Horatio's exposition in the opening scene. While Horatio is repeating, for the benefit of the audience, information which is open and accessible to anyone in Elsinore, the Ghost discloses to Hamlet a secret buried in the past. 
The story of the murder is not only narrated in the play, but is also re-enacted, in a highly stylized form, in the play-within-the-play. In this scene we are given an opportunity to see for ourselves another version of the events recounted by the Ghost. The events are enacted twice over, first in dumb show, then in a highly rhetorical play, which is broken up in the middle by Claudius.

The popular Elizabethan technique of presenting another play in front of the characters creates an interesting spatial effect. A new theatrical space is made room for in the midst of the visible theatrical space. This is clearly indicated in performance by the differentiation between the stage-audience and the space cleared by them for the performers.

Thus, within the confined theatrical space of Elsinore, Shakespeare introduces yet another theatrical space, which belongs to another play, variously called The Murder of Gonzago, or The Mousetrap. This fourth theatrical space is created by the tragedians of the city, travellers from the theatrical space without, and purports to represent events that took place in Vienna, another place in the virtual geography. Moreover, the inner play represents that event narrated by the Ghost, a figure belonging to the undiscover'd country. Thus, the space of the inner performance cuts across the other distinct theatrical places and relates them to each other. This added theatrical space is of a complex nature : it belongs to the inner visible core of the theatrical space, but also to the levels of the theatrical space outside, i.e. the virtual geography and the undiscover'd country.

The performance of the play-within-the-play lies at the heart of the drama. Structurally, it is centrally positioned, in Act III scene 2. Dramatically, it is the turning point. It confirms the mutual recognition of murderer and avenger, and precipitates their actions. To this extent, the scene constitutes a classical climax combining recognition with reversal.

The spatial apartness of the Gonzago play is achieved not only through its mode of presentation on stage. It is already present in the artistic articulation of the scene as a whole. By different means, the inner play is distanced from its surroundings. The situation it 
presents is very much analogous to the state of affairs that led to the murder of Hamlet senior. But compared with Hamlet, the idiom of the Gonzago play is rhetorical and artificial. The archaic flavour is nowhere more noticeable than in the murderer Lucianus's self-declaration :

Thoughts black, hands apt, drugs fit and time agreeing, etc.

(III 2, 255)

The artificiality of style and characterization precludes any empathy and contributes to the emotional distancing of The Mousetrap. The old-fashioned play is further alienated by the interpolated remarks of the royal audience. Hamlet seems to be deliberately attempting to alienate even further the performance when he explains that the play represents

... the image of a murther done in Vienna; Gonzago is the duke's name, his wife, Baptista... 'Tis a knavish piece of work, but what of that?. Your Majesty, and we that have free souls, it touches us not. Let the gall'd jade winch, our withers are unwrung.

(III 2, 238-243)

At the moment of the poisoning, Hamlet again insists that

the story is extant, and written in very choice Italian,

(III 2, 262-3)

which has sent many a scholar scurrying for the lost source. Hamlet pretends to be blind to the immediate implications of the play, while the anxiety and consternation of the royal couple is perceptibly rising. By distancing the Gonzago play as much as possible from his own play, Shakespeare emphasizes its separate theatrical space.

Hamlet's coy insistence on the play as representing an Italian story fools neither the royal audience on stage nor the real audience in the auditorium. In the inner play we are treated to a belated dramatization of the murder, which is transferred from its initial position in the sequence of events to a structurally central position. 
It is so manipulated that, from a mere pretext for the action, it becomes its very apex. The scene of the murder is temporally dislocated for artistic effect.

The killing of the king is treated differently in Macbeth. There, the murder is committed off-stage, while the spectators are obliged to wait with Lady Macbeth in an adjoining room in order to find out what has happened in the royal bedchamber. The noises which pierce the silent night, the shrieking of the owl and Macbeth's cries, increase the credibility of the theatrical space without, where the crucial event is taking place. Rather than let us witness the murder, the playwright prefers to let us experience it from Lady Macbeth's perspective.

In Macbeth, the murder occurs in the present, in real stage time, but in an imagined theatrical space outside. In Hamlet, on the other hand, it is the time, and not the place, of the murder that is manipulated, so that the action which, in terms of the plot, belongs to the past, appears in the theatrical present, in the visible theatrical space. In the play-within-the-play scene, temporal relations are translated into spatial relations : the past is depicted as the theatrical space of the Gonzago play, the present as the theatrical space of Elsinore.

The temporal relations between present and past are of great thematic importance to the play. The past continues to be with us in the form of memory. The problem of memory permeates the play for good reason: as Claudius's crime is undetected, there can be no memory of it, except in his own mind. In his very first words in the play, the King chooses "remembrance of ourselves" over the " green " memory of his late brother (I 2, 1-7). Claudius whishes to forget the past and get on with the present business of state.

He might have had his way if it were not for the appearance of the Ghost, who reveals to Hamlet the details of the murder and demands both remembrance and revenge. From this point on, the murder has existence in Hamlet's memory, and there alone. His encounter with the Ghost makes Hamlet a repository of a secret 
which calls upon him to act. The secret draws him away from his friends, makes him withdraw into himself.

Even before his encounter with the Ghost, Hamlet is obsessed with memory. His black garments and melancholy disposition single him out in court as the only one who still remembers the dead King. His mother pleads with him to stop seeking for his noble father in the dust (I 2, 70-71), while Claudius unctuously suggests that he "think of us as of a father" (I 2, 107-108), in other words, that he forget his own father. Thus the Ghost's injunction "Remember me " falls on willing ears.

In his production of The Murder of Gonzago, Hamlet gives dramatic and public shape to his private memory of the murder. ${ }^{6}$ As he has not himself witnessed the event, this imaginative presentation is highly biased. Hamlet's choric comments direct our attention to the uneasy subject of death and remarriage. First discussed by Hamlet and Horatio, this topic forms the subject-matter of the conversation between Player King and Player Queen. The dialogue is deliberately artificial, aimed at exposing the Queen's hypocrisy and infidelity. The murderer enters only after the Queen's excessive protestations of fidelity. As Hamlet had foreseen, the sight of the poisoning is too much for the King's guilty conscience, and he breaks the performance at this point.

Celebrating this outcome, Hamlet congratulates himself on his artistry :

Would not this, sir,... get me a fellowship in a cry of players ?

(III 2, 275-277)

Hamlet feels great affinity with the players. In the " $\mathrm{O}$, what a rogue and peasant slave am I" soliloquy, he compares his own inability to work up a passion to the actor's ability to simulate one. But he shares with the actors the power of memory, for he can repeat a long section of the Pyrrhus speech he once heard. His easy relations with the actors, the agility with which he himself can enter their sport and his keen interest in the aesthetics of the theatre characterize him as a Renaissance patron of drama. His ease in entering the spirit of their play may be compared with Sir Thomas More's joining in with the Interlude players in The Book of Sir Thomas More. 
For Hamlet, theatre is not a mere entertainment, as it is for the rest of the court. He sees in it an important ethical and psychological tool for the investigation of human motivation and behaviour. For him, it is a mirror held up to nature, in which the spectators can see themselves and their problems reflected (III 2).

Hamlet suggests that the players act as a sort of collective social memory,

they are the abstract and brief chronicles of the time. After your death you were better have a bad epitaph than their ill report while you live.

(II $2,524-526)$

For as long as the play Hamlet is performed, people will continue to remember its particular set of events. This same theatrical selfawareness is voiced by Cassius in the assassination scene of Julius Caesar :

... How many ages hence

Shall this our lofty scene be acted over,

In states unborn and accents yet unknown.

(Julius Caesar, III 1, 111-113)

But Shakespeare's play does not record the action as it took place, in a naturalistic manner. Like Hamlet, Shakespeare has no first-hand memory of the event but only a reported one. His version, stylized and contrived, becomes the public, collective memory. Whether the event it records is historical or mythical, the theatrical re-enactment cannot recreate the event without also creating the separate theatrical space in which only the event can again take place. Memory can be visually externalized only in such a specially circumscribed space with its own inner time and logic.

\section{VI}

Ironically, the last scene of the play dispatches practically all the protagonists of the play to the undiscover'd country. Elsinore is no longer a prison because there is no one left in it. The bodies are 
ceremoniously carried out. The vacuum at the centre is filled by the Norwegian Prince coming from the geographical periphery. The hermetically sealed boundaries between the various theatrical spaces have been temporarily lifted until a new order is imposed. The ending of the play in fact destroys the theatrical spaces it had so carefully set up.

\author{
Hanna SCOLNICOV \\ The Hebrew University of Jerusalem
}

NOTES

1) Although in stage directions a character goes "in " when he exits the stage and comes " out " when he enters it, it suits better the nature of my argument to call the on-stage "within" and the off-stage "without». See further H. Scolnicov, "Theatre Space, Theatrical Space, and the Theatrical Space Without", in J. Redmond, ed., The Theatrical Space, Themes in Drama 9 (Cambridge), 1987, pp. 11-26.

2) Cf. C. Perelman's comment on M. Dufrenne, "L'espace dans l'art ", in L'espace/ Space, Institut International de Philosophie, Entretien de Bern 1976 (Bern, 1978), p. 242.

3) Dover Wilson and others have traced specific allusions to the Lord Admiral's Men, Edwarde Alleyn and the Globe Theatre. Cf. J. D. Wilson, What Happens in Hamlet (Cambridge, 1935), Appendix C : "The Identity of the Gonzago Troupe ».

4) J. M. Nosworthy, Shakespeare's Occasional Plays (London, 1965), p. 174.

5) Cf. N. Alexander, Poison, Play and Duel (London, 1971), pp. 35-36.

6) There is an uncanny resemblance between the representation of the murder of the King in the play-within-the-play and the first mnemonic image suggested in Ad Herenium, quoted by F. Yates, The Art of Memory (London, 1966 ; repr. 1978), p. 27. The great popularity of Ad Herenium in the Renaissance would make one think that the resemblance is not accidental. 